\title{
DRIS norms validation for sugarcane $\operatorname{crop}^{(1)}$
}

\author{
Roberto dos Anjos Reis Junior ${ }^{(2)}$ and Pedro Henrique Monnerat ${ }^{(3)}$
}

\begin{abstract}
The objectives of this study were to evaluate the relationship between the diagnosis and recommendation integrated system (DRIS) indices and foliar nutrient concentrations, to establish optimum foliar nutrient concentrations with DRIS and to validate the DRIS norms for sugarcane crop. Foliar nutrient concentrations from 126 sugarcane commercial fields were analyzed during the 1996/97 season, to calculate DRIS indices. Regression analysis was used to fit a model relating DRIS indices to nutrient concentrations. Experiments were carried out during the 1997/98 season, whose treatments consisted of the addition of the most limiting nutrients according to DRIS. A new diagnosis was performed. At the end of 1997/98 season, the yields of each plot were collected. Analysis of variance and Duncan test $(5 \%)$ were used for the evaluation of the collected data. There was a positive and significant relationship between sugarcane foliar nutrient concentrations and DRIS indices. The optimum foliar nutrient concentrations for sugarcane are: $13.4 \mathrm{~g} \mathrm{ha}^{-1}$ for $\mathrm{N}, 1.91 \mathrm{~g} \mathrm{ha}^{-1}$ for $\mathrm{P}, 12.2 \mathrm{~g} \mathrm{ha}^{-1}$ for $\mathrm{K}, 2.99 \mathrm{~g} \mathrm{ha}^{-1}$ for Ca, 2.15 $\mathrm{g} \mathrm{ha}^{-1}$ for $\mathrm{Mg}, 1.61 \mathrm{~g} \mathrm{ha}^{-1}$ for $\mathrm{S}, 4.48 \mathrm{mg} \mathrm{ha}^{-1}$ for $\mathrm{Cu}, 67.8 \mathrm{mg} \mathrm{ha}^{-1}$ for Mn and $11.7 \mathrm{mg} \mathrm{ha}^{-1}$ for $\mathrm{Zn}$. DRIS norms evaluated are useful to correct nutritional imbalances and to increase sugarcane yield.
\end{abstract}

Index terms: Saccharum officinarum, foliar nutrient content, plant analysis, nutritional status, productivity.

\section{Validação de normas DRIS para a cultura da cana-de-açúcar}

Resumo - Os objetivos deste trabalho foram avaliar a relação entre os índices DRIS (Diagnosis and Recommendation Integrated System) e os teores foliares de nutrientes, estabelecer teores foliares adequados de nutrientes com o DRIS e validar normas DRIS para a cana-de-açúcar. Teores foliares de nutrientes de 126 lavouras comerciais de cana-de-açúcar foram analisados durante a safra 1996/97, para o cálculo de índices DRIS. Análise de regressão foi utilizada para ajustar modelo relacionando índices DRIS e teores foliares de nutrientes. Os experimentos foram conduzidos na safra 1997/98, e os tratamentos consistiram na adição dos nutrientes mais limitantes de acordo com a diagnose fornecida pelo DRIS. Posteriormente, nova diagnose nutricional foi realizada. No final da safra 1997/98, foram avaliadas as produtividades das parcelas experimentais. Análise de variância e teste de médias (Duncan, 5\%) foram utilizados na avaliação dos dados coletados. Houve relação positiva e significativa entre teores foliares e índices DRIS. Os teores foliares adequados de nutrientes estabelecidos foram: $13,4 \mathrm{~g} \mathrm{ha}^{-1}$ de N; 1,91 $\mathrm{g} \mathrm{ha}^{-1}$ de P; 12,2 $\mathrm{g} \mathrm{ha}^{-1}$ de K; 2,99 $\mathrm{g} \mathrm{ha}^{-1}$ de Ca; 2,15 $\mathrm{g} \mathrm{ha}^{-1}$ de Mg; 1,61 $\mathrm{g} \mathrm{ha}^{-1}$ de S; 4,48 mg ha ${ }^{-1}$ de $\mathrm{Cu} ; 67,8 \mathrm{mg} \mathrm{ha}^{-1}$ de Mn e 11,7 $\mathrm{mg} \mathrm{ha}^{-1} \mathrm{de} \mathrm{Zn}$. As normas DRIS avaliadas foram úteis na correção dos desequilíbrios nutricionais e no aumento da produtividade da cana-de-açúcar.

Termos para indexação: Saccharum officinarum, teor foliar de nutrientes, análise vegetal, estado nutricional, produtividade.

(1) Accepted for publication on July 22, 2002.

Extracted from the D.Sc. thesis presented by the first author at Universidade Estadual do Norte Fluminense (Uenf), Campos dos Goytacazes, RJ.

(2) Fundação Chapadão, Rod. MS 306, km 105, Caixa Postal 39, CEP 79560-000 Chapadão do Sul, MS, Brasil. Email: reisjr@hotmail.com

(3) Uenf, Centro de Ciências e Tecnologias Agropecuárias, CEP 28015-620 Campos dos Goytacazes, RJ, Brasil. E-mail: monnerat@uenf.br

\section{Introduction}

Plant analysis can be a useful tool for correcting plant nutrient deficiencies and imbalances (Baldock \& Schulte, 1996), optimizing crop production (Walworth et al., 1986), and for evaluating fertilizer requirements. The Diagnosis and Recommendation Integrated System (DRIS) is a recent approach to 
interpreting plant-tissue analysis. This methodology has received considerable attention since it was developed by Beaufils (1973).

The DRIS system makes multiple two-way comparisons between the levels of various plant nutrients and integrates these comparisons into a series of nutrient indices (Walworth et al., 1986). The DRIS index scale that results from those calculations is continuous and easy to understand (Baldock \& Schulte, 1996). This model is designed to determine when the nutrient contents of crops are excessive (positive indices), adequate (zero indices) or deficient (negative indices). Development of the DRIS for use with a crop involves compiling a database (Payne et al., 1990) from which optimum ratios (mean and coefficient of variance) for all nutrient combinations are determined (Snyder et al., 1989), called DRIS norms.

Several authors have affirmed that, after being developed for a plant species, the DRIS norms can be used irrespective of the cultivar grown or local conditions (Sumner, 1979; Walworth \& Sumner, 1987; Payne et al., 1990), but others found that locally developed DRIS norms are more accurate than the broad based norms in their nutrient diagnoses (Dara et al., 1992; Jones Junior, 1993). This demonstrates that DRIS norms, calculated on the basis of finite sets of field data, must be tested to insure validity and accuracy (Walworth \& Sumner, 1987). To do this, DRIS diagnosis are usually conducted on greenhouse or field-grown plants from fertilizer surveys. Caldwell et al. (1994) used NxPxKxS and NxPxK factorials to evaluate DRIS norms for onions, in which the diagnoses were considered accurate, if the next treatment containing the nutrient identified as limiting resulted in an yield increase.

The relationship between yield and plant nutrient concentration is a premise to use the plant analysis as diagnostic criterion. So, the relationship between nutrient concentration and DRIS indices may be a valuable criterion to validate the DRIS norms. If there is a relationship between plant nutrient concentration and DRIS index, this index can be used to make nutritional diagnosis. Probably, this is a new way to validate DRIS norms. This fitted model between nutrient concentration and respective DRIS index probably shows negative and positive DRIS index, and it could be used to determine optimum foliar concentration, because the nutrient foliar concentration at null DRIS index possibly do not limit crop yield. If the crop shows nutrient concentrations higher or lower than this optimum value, the crop shows positive or negative DRIS indices respectively, which indicate yield limitation by nutritional excess or deficiency.

The objectives of this study were to evaluate the relationship between DRIS indices and foliar nutrient concentrations, to establish optimum foliar nutrient concentrations with DRIS and to validate the DRIS norms for sugarcane crop.

\section{Material and Methods}

The relationship between DRIS indices and foliar nutrient concentrations were evaluated with the sugarcane foliar nutrient concentrations from the database built by Reis Junior \& Monnerat (2003). DRIS indices for all database were established with DRIS norms developed by Reis Junior \& Monnerat (2003), according to Beaufils (1973), through a sheet developed in MS-Excel 2000 for IBM-PC. The sensitivity coefficient (k) used in DRIS calculations was equal to ten. Regression analysis was used to fit a model that relates DRIS indices to nutrient contents as the independent variable. The best fitting model was chosen among the linear and logarithm $[y=a+b \ln (x)]$ models. The optimum foliar concentrations with DRIS were established by the determination of the nutrient content that produce the null DRIS index.

Field experiments were used to validate sugarcane DRIS norms (Reis Junior \& Monnerat, 2003). Leaves from three sugarcane ratoon experiments, conducted at Bambuzal (field 1), Duas Barras II (field 2) and Fazendinha (field 3), in the State of Rio de Janeiro, Brazil, were sampled and analyzed during the 1996/97 season. The method of sampling and chemical tissue analysis were described in Reis Junior \& Monnerat (2003). DRIS indices were calculated with the results of these foliar analyses. The sensitivity coefficient $(\mathrm{k})$ used in DRIS calculations was equal to ten.

At the end of the 1996/97 season, the yield of each field was determined and a fertilizer survey was carried out in each field after sugarcane harvest. The respective results of foliar analysis, DRIS indices and yield from the 1996/97 season are in Table 1. These results of foliar analysis were also compared with the sufficient range for sugarcane proposed by Orlando Filho \& Campos (1975a, 1975b), Orlando Filho \& Haag (1976), Orlando Filho \& Zambello Junior (1977), Orlando Filho et al. (1979, 1980a, 1980b, 1980c) and Malavolta et al. (1997). 
After sugarcane harvest of 1996/97 season, soil samples were collected from a layer of 0-200 mm and 200-400 mm in the fields 1, 2 and 3. Each composite soil sample was made up from 15 simple samples randomly collected, in the planting rows and in an area of 1 ha, approximately. Soil physical and chemical ( $\mathrm{pH}$ and $\mathrm{P}, \mathrm{K}, \mathrm{Ca}, \mathrm{Mg}$ and $\mathrm{Al}$ concentrations) features were determined according to Embrapa (1979) (Table 2). A fertilizer survey was carried out in each sampled field during 1997/98 season, as described below.

The treatments of the experiments consisted of the addition of the most limiting nutrients according to DRIS and sufficient range. This DRIS diagnosis was performed with preliminary DRIS norms based on yield expectation of the samples collected during 1996/97 season. After the fertilizer survey installation, some expected yields from the sampled fields (data bank) were not confirmed, which resulted in differences between the preliminary and definitive DRIS norms. Thus, some nutrients that were not indicated as limiting were used in the experiment, while others, that were indicated as limiting, were not used.

Nitrogen and zinc showed negative DRIS indices and foliar concentrations below the sufficient range, while $\mathrm{Cu}$ showed a foliar content below the sufficient range in the 1996/97 diagnosis in the experiment at Bambuzal (field 1) (Table 1). Therefore, the treatments were: control and $\mathrm{N}+$ $\mathrm{Cu}+\mathrm{Zn}$. The prior sugarcane harvest in this field was performed on 7/1/97, and on 8/4/97 $\mathrm{N}\left(100 \mathrm{~kg} \mathrm{ha}^{-1}\right.$ as urea), $\mathrm{Cu}\left(6 \mathrm{~kg} \mathrm{ha}^{-1}\right.$ as $\left.\mathrm{CuSO}_{4}\right)$ and $\mathrm{Zn}\left(6 \mathrm{~kg} \mathrm{ha}^{-1}\right.$ as $\left.\mathrm{ZnSO}_{4}\right)$ were banded close to the sugarcane rows only in the $\mathrm{N}+$ $\mathrm{Cu}+\mathrm{Zn}$ treatment. The experiment was set up in randomized blocks, replicated four times. Each plot consisted of 14 rows of $80 \mathrm{~m}$ spaced $1.2 \mathrm{~m}$ and the useful rows were those 12 central. All plots received $100 \mathrm{~kg} \mathrm{ha}^{-1}$ of $\mathrm{KCl}$. On 7/7/98 sugarcane variety RB 73-9735 was harvested and yield was evaluated.

Table 1. Foliar nutrient contents, DRIS indices, nutrient balance index (NBI) and yield of three sugarcane fields, at Bambuzal, Duas Barras II and Fazendinha, in the State of Rio de Janeiro, Brazil. 1996/1997.

\begin{tabular}{|c|c|c|c|c|c|c|c|c|c|c|c|}
\hline Variable & $\begin{array}{l}\mathrm{N} \text {-org } \\
\end{array}$ & $P$ & $\begin{array}{l}\mathrm{K} \\
-(\mathrm{g} \mathrm{k}\end{array}$ & $\mathrm{Ca}$ & $\mathrm{Mg}$ & $S$ & $\mathrm{Cu}$ & $\begin{array}{c}\mathrm{Mn} \\
\left(\mathrm{mg} \mathrm{kg}^{2}\right.\end{array}$ & Zn & NBI & $\begin{array}{c}\text { Yield } \\
\left(\mathrm{Mg} \mathrm{ha}^{-1}\right)\end{array}$ \\
\hline & \multicolumn{11}{|c|}{ Bambuzal } \\
\hline Foliar content & $12.8^{(1)}$ & 2.06 & 11.2 & $4.63^{(1)}$ & 2.89 & $1.67^{(1)}$ & $5.50^{(1)}$ & 67.0 & $11.4^{(1)}$ & 50 & 77.3 \\
\hline DRIS indices & -6 & 1 & -2 & 10 & 6 & -4 & 8 & -2 & -11 & & \\
\hline & \multicolumn{11}{|c|}{ Duas Barras II } \\
\hline Foliar content & $12.6^{(1)}$ & $1.37^{(1)}$ & 10.0 & $3.38^{(1)}$ & $1.65^{(1)}$ & $0.78^{(1)}$ & $4.17^{(1)}$ & 139.5 & $9.15^{(1)}$ & 160 & 39.0 \\
\hline DRIS indices & 4 & -10 & 4 & 9 & -8 & -50 & 7 & 56 & -12 & & \\
\hline & \multicolumn{11}{|c|}{ Fazendinha } \\
\hline Foliar content & $10.9^{(1)}$ & 2.51 & $8.81^{(1)}$ & 7.22 & 3.54 & $1.08^{(1)}$ & $5.26^{(1)}$ & 64.4 & $14.4^{(1)}$ & 158 & 73.5 \\
\hline DRIS indices & -19 & 16 & -15 & 34 & 17 & -41 & 5 & -4 & 7 & & \\
\hline
\end{tabular}

${ }^{(1)}$ Concentration below sufficient range.

Table 2. Soil chemical analysis of the fertilizer trials at Bambuzal (field 1), Duas Barras II (field 2) and Fazendinha (field 3), in the State of Rio de Janeiro, Brazil. 1997/1998.

\begin{tabular}{|c|c|c|c|c|c|c|c|c|c|c|c|}
\hline Field & $\mathrm{pH}$ & ----- ( & $\left.y^{-1}\right)----$ & $----\cdot$ & $-(\mathrm{mm}$ & $\left.g^{-1}\right)$ & ------- & $\begin{array}{c}\text { Sand } \\
\text { coarse } \\
-\end{array}$ & $\begin{array}{l}\text { Sand } \\
\text { fine }\end{array}$ & 1) --- & ------ \\
\hline \multicolumn{12}{|c|}{$0-200 \mathrm{~mm}$ layer } \\
\hline 1 & 6.2 & 3 & 140 & 39 & 42 & 1 & 29.7 & 30 & 140 & 290 & 540 \\
\hline 2 & 4.8 & 4 & 150 & 20 & 17 & 13 & 61.0 & 237 & 116 & 47 & 600 \\
\hline 3 & 5.6 & 4 & 103 & 62 & 34 & 0 & 54.5 & 48 & 89 & 343 & 520 \\
\hline \multicolumn{12}{|c|}{$200-400 \mathrm{~mm}$ layer } \\
\hline 1 & 6.2 & 1 & 112 & 29 & 41 & 0 & 24.8 & 30 & 90 & 280 & 600 \\
\hline 2 & 4.7 & 2 & 45 & 10 & 10 & 15 & 46.0 & 295 & 177 & 28 & 500 \\
\hline 3 & 5.9 & 3 & 65 & 54 & 28 & 0 & 49.5 & 45 & 99 & 316 & 540 \\
\hline
\end{tabular}


Sulfur and $\mathrm{P}$ showed negative DRIS indices and a foliar content below sufficient range, while $\mathrm{Cu}$ showed a foliar content below the sufficient range in the 1996/97 diagnosis in the experiment at Duas Barras II (field 2) (Table 1). Therefore, the treatments were: control, $\mathrm{P}+\mathrm{S}+\mathrm{Cu} ; \mathrm{S}+$ $\mathrm{Cu}$ and $\mathrm{S}$. The prior sugarcane harvest in this field was performed on 9/12/97, and on 10/12/97 P (41 kg ha-1 of $\mathrm{P}_{2} \mathrm{O}_{5}$ as single superphosphate), $\mathrm{S}$ (50 $\mathrm{kg} \mathrm{ha}^{-1}$ as gypsum) and $\mathrm{Cu}\left(6 \mathrm{~kg} \mathrm{ha}^{-1}\right.$ as $\left.\mathrm{CuSO}_{4}\right)$ were banded close to the sugarcane rows. The experiment was set up in randomized blocks, replicated four times. Each plot consisted of eight rows of $90 \mathrm{~m}$ spaced $1.2 \mathrm{~m}$ and the useful rows were those six central. All plots received $230 \mathrm{~kg} \mathrm{ha}^{-1}$ of $25-0-25$. The sugarcane (variety SP 70-1143) harvest and yield evaluation were anticipated to 7/14/98 because of an accidental sugarcane burning which happened in this field.

Nitrogen, $\mathrm{K}$ and $\mathrm{S}$ showed negative DRIS indices and foliar concentrations below the sufficient range in the 1996/97 diagnosis in the experiment at Fazendinha (field 3) (Table 1). Therefore, the treatments were: control and $\mathrm{N}+$ $\mathrm{K}+\mathrm{S}$. The prior sugarcane harvest in this field was performed on 9/23/97, and on 10/19/97 N (100 kg ha-1 as ammonium sulfate and urea), $\mathrm{K}$ (90 $\mathrm{kg} \mathrm{ha}^{-1}$ of $\mathrm{K}_{2} \mathrm{O}$ as $\mathrm{KCl}$ ) and $\mathrm{S}$ (50 kg ha-1 as gypsum) were banded close to the sugarcane rows. The experiment was set up in randomized blocks, replicated four times. Each plot consisted of 14 rows of $100 \mathrm{~m}$ spaced $1.2 \mathrm{~m}$ and the useful rows were those 12 central. On 10/23/98, sugarcane (variety RB 73-9735) was harvested and yield was evaluated.

Throughout the growing season, the production system was managed, according to the management practices recommended in the region, which included irrigation as needed. Leaf samples were collected in each plot of the experiment, four months after plant sprouting, analyzed as described by Reis Junior \& Monnerat (2003), and then a new diagnosis was performed with DRIS.

Analysis of variance and Duncan test (5\%) were used for the evaluation of the collected data.

\section{Results and Discussion}

Statistical models were fitted between all foliar nutrient concentrations and respective DRIS indices. All DRIS indices increased with respective nutrient concentrations. The fitted models show points where the DRIS indices are equal to zero (Figure 1). The nutrient foliar concentration at these points possibly do not limit crop yield because its DRIS index is null. It was possible to make this hypothesis because the database used to fit these models was built with only one sampling time, and thus, the plant age effect on nutrient concentration is discharged, which allowed the nutrient concentration associated to null index to be used in nutritional diagnosis, similarly to the adequate level. This can be a new way to determine optimum nutrient concentrations to obtain high yields. The optimum foliar nutrient concentrations for sugarcane are: $13.4 \mathrm{~g} \mathrm{ha}^{-1}$ for N, $1.91 \mathrm{~g} \mathrm{ha}^{-1}$ for $\mathrm{P}$, $12.2 \mathrm{~g} \mathrm{ha}^{-1}$ for K, $2.99 \mathrm{~g} \mathrm{ha}^{-1}$ for Ca, $2.15 \mathrm{~g} \mathrm{ha}^{-1}$ for $\mathrm{Mg}$, $1.61 \mathrm{~g} \mathrm{ha}^{-1}$ for $\mathrm{S}, 4.48 \mathrm{mg} \mathrm{ha}^{-1}$ for $\mathrm{Cu}, 67.8 \mathrm{mg} \mathrm{ha}^{-1}$ for $\mathrm{Mn}$ and $11.7 \mathrm{mg} \mathrm{ha}^{-1}$ for Zn. Only N, Ca, S, Cu and Zn contents were below the sufficient range proposed by Orlando Filho \& Campos (1975a, 1975b), Orlando Filho \& Haag (1976), Orlando Filho \& Zambello Junior (1977), Orlando Filho et al. (1979, 1980a, 1980b, 1980c) and Malavolta et al. (1997).

There was not a significant difference between foliar nutrient contents and sugarcane yield on treatment control and $\mathrm{N}+\mathrm{Cu}+\mathrm{Zn}$ in the field 1 , although the application of $\mathrm{N}, \mathrm{Cu}$ and $\mathrm{Zn}$ fertilizer was performed. Copper and $\mathrm{Zn}$ limitation, according to DRIS, observed in the $1996 / 97$ season was observed also during the diagnosis realized in the 1997/98 season (Table 3). Calcium and Mn limitation also appeared during the last diagnosis according to DRIS. Nitrogen, $\mathrm{Ca}, \mathrm{Cu}, \mathrm{Mn}$ and $\mathrm{Zn}$ content during the 1997/98 diagnosis were below the sufficient range proposed for sugarcane.

The mean sugarcane yields obtained in this field during the 1996/97 and 1997/98 seasons were higher than the average yield of Brazil. Probably the low Nutrient Balance Index (NBI) found with DRIS during the 1996/97 diagnosis and the fact that the DRIS indices are near to zero indicate that any nutritional correction should not be done in this field even with the presence of negative DRIS indices. There are authors that do not consider a nutrient deficiency when the DRIS indices are negative and near to zero. Soltanpour et al. (1995) take into consideration only DRIS indices of -7 or lower to indicate nutrient deficiency in corn.

Only foliar S concentration was significantly affected by the treatments $(p \leq 0.01)$ in the field 2 . The application of $\mathrm{P}$ and $\mathrm{Cu}$ fertilizer did not increased foliar $\mathrm{P}$ and $\mathrm{Cu}$ concentration, but the application of $\mathrm{S}$ fertilizer increased foliar S content. The P, S and $\mathrm{Mg}$ limitation according to DRIS observed in the 

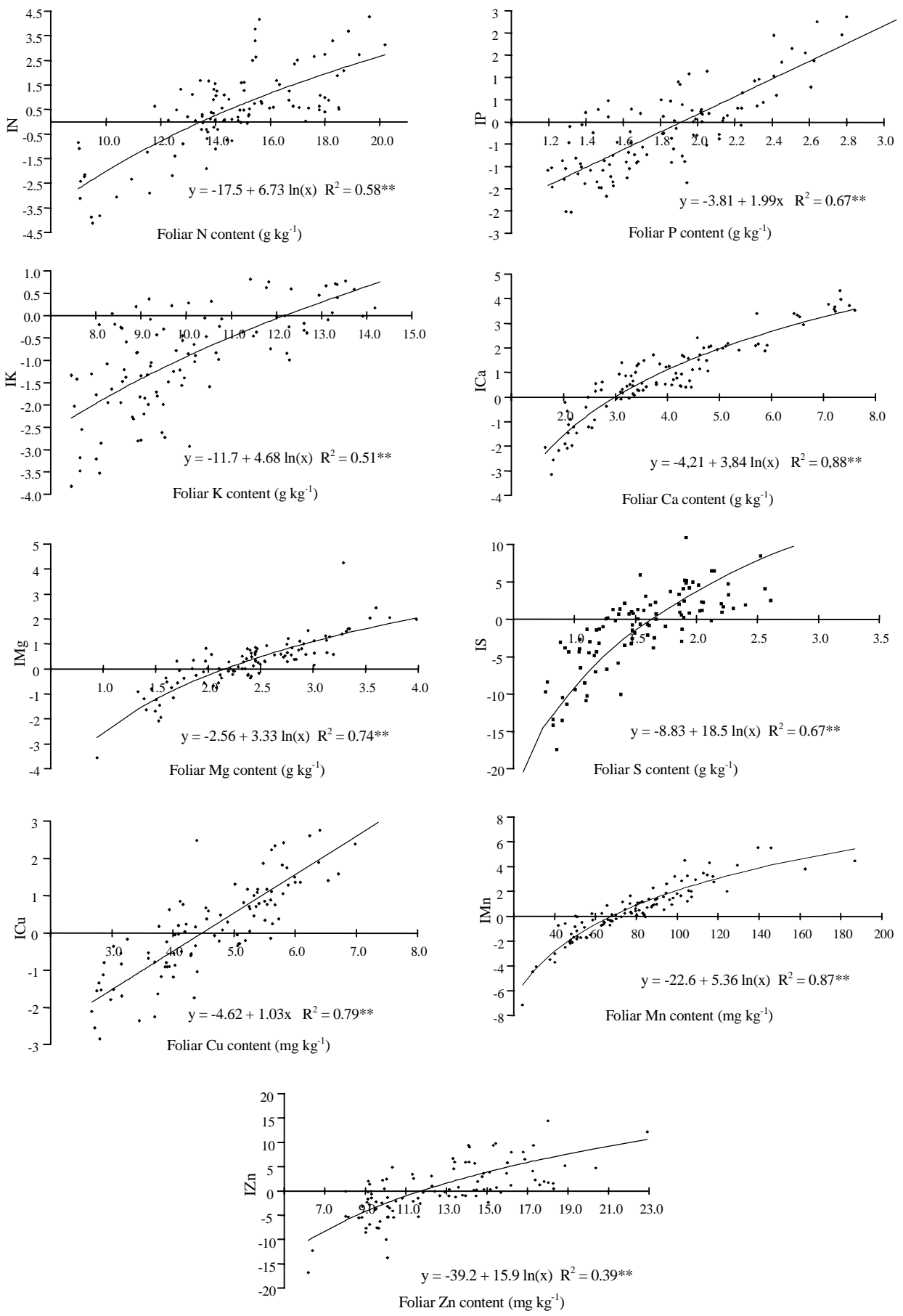

Figure 1. Relationship between $\mathrm{N}, \mathrm{P}, \mathrm{K}, \mathrm{Ca}, \mathrm{Mg}, \mathrm{S}, \mathrm{Cu}, \mathrm{Mn}$ and $\mathrm{Zn}$ DRIS indices (I) and respective foliar contents. 
Table 3. The mean foliar content (FC), DRIS indices (DI), nutrient balance index (NBI) and sugarcane yield from the fertilizer surveys, at Bambuzal, Duas Barras II and Fazendinha, in the State of Rio de Janeiro, Brazil. 1997/1998(1).

\begin{tabular}{|c|c|c|c|c|c|c|c|c|c|c|c|c|c|}
\hline Treatment & & $\mathrm{N}$ & $P$ & $\begin{array}{c}\mathrm{K} \\
--\mathrm{g} \mathrm{k} \mathrm{k}\end{array}$ & $\begin{array}{l}\mathrm{Ca} \\
1)\end{array}$ & $\mathrm{Mg}$ & S & \multicolumn{5}{|c|}{----- $\left(\mathrm{mg} \mathrm{kg}^{-1}\right)$----- } & $\begin{array}{c}\text { Yield } \\
\text { (Mg ha }^{-1}\end{array}$ \\
\hline & \multicolumn{13}{|c|}{ Bambuzal } \\
\hline Mean & $\mathrm{FC}$ & 16.4 & 2.26 & 13.1 & 3.07 & 3.38 & 2.71 & 4.95 & 35.4 & 15.0 & & & \\
\hline \multirow[t]{2}{*}{ values } & DI & 7 & 4 & 2 & -6 & 12 & 26 & -2 & -44 & 1 & 0 & 104 & 86.9 \\
\hline & \multicolumn{13}{|c|}{ Duas Barras II } \\
\hline \multirow[t]{2}{*}{ Control } & $\mathrm{FC}$ & 15.3 & 1.54 & 10.9 & 2.01 & 1.48 & $1.31 \mathrm{~b}$ & 3.53 & 133.0 & 14.4 & & & \\
\hline & DI & 9 & -8 & 1 & -16 & -16 & -13 & -12 & 42 & 13 & 0 & 130 & 43.1 \\
\hline \multirow[t]{2}{*}{$\mathrm{P}+\mathrm{S}+\mathrm{Cu}$} & $\mathrm{FC}$ & 15.3 & 1.54 & 10.9 & 2.01 & 1.48 & $1.45 \mathrm{a}$ & 3.53 & 133.0 & 14.4 & & & \\
\hline & DI & 8 & -8 & 0 & -16 & -17 & -7 & -13 & 41 & 12 & 0 & 122 & 43.1 \\
\hline \multirow[t]{2}{*}{$\mathrm{S}+\mathrm{Cu}$} & $\mathrm{FC}$ & 15.3 & 1.54 & 10.9 & 2.01 & 1.48 & $1.45 \mathrm{a}$ & 3.53 & 133.0 & 14.4 & & & \\
\hline & DI & 8 & -8 & 0 & -16 & -17 & -7 & -13 & 41 & 12 & 0 & 122 & 43.1 \\
\hline \multirow[t]{3}{*}{$S$} & $\mathrm{FC}$ & 15.3 & 1.54 & 10.9 & 2.01 & 1.48 & $1.46 \mathrm{a}$ & 3.53 & 133.0 & 14.4 & & & \\
\hline & DI & 8 & -8 & 0 & -16 & -17 & -7 & -13 & 41 & 12 & 0 & 122 & 43.1 \\
\hline & \multicolumn{13}{|c|}{ Fazendinha } \\
\hline \multirow[t]{2}{*}{ Control } & $\mathrm{FC}$ & 12.1 & 2.58 & 8.63 & 4.40 & 2.31 & 1.47 & 3.76 & 46.8 & 16.5 & & & \\
\hline & DI & -7 & 22 & -13 & 12 & 1 & -9 & -13 & -15 & 22 & 0 & 114 & 83.5 \\
\hline \multirow[t]{2}{*}{$\mathrm{N}+\mathrm{K}+\mathrm{S}$} & $\mathrm{FC}$ & 14.41 & 2.58 & 9.59 & 4.40 & 3.16 & 1.72 & 4.28 & 46.81 & 16.54 & & & \\
\hline & DI & -1 & 15 & -11 & 9 & 10 & -4 & -10 & -21 & 13 & 0 & 94 & 104.7 \\
\hline
\end{tabular}

${ }^{(1)}$ For the same location values in the same column followed by the same letter do not differ at $5 \%$ of probability by the Duncan test.

1996/97 season repeated during the diagnosis carried out in the 1997/98 season. Foliar N, P, Ca, Mg, S, Cu and $\mathrm{Zn}$ concentration in the treatment control during the 1997/98 diagnosis were below the sufficient range proposed for sugarcane.

The NBI was reduced with the application of $S$ fertilizer, which indicates that the application of this fertilizer aids the crop to be near the nutritional balance. The yield did not increase with the application of fertilizers. Probably, the reduction of the sugarcane cycle, in terms of the accidental sugarcane burning, did not allowed the appearance of yield differences between the treatments (Table 3).

The application of $\mathrm{N}+\mathrm{K}+\mathrm{S}$ fertilizer increased foliar $\mathrm{N}(\mathrm{p} \leq 0.01), \mathrm{K}(\mathrm{p} \leq 0.05), \mathrm{Mg}(\mathrm{p} \leq 0.01), \mathrm{S}(\mathrm{p} \leq 0.01)$, and $\mathrm{Cu}$ concentration $(\mathrm{p} \leq 0.05)$ in the field 3 . Nitrogen, $K$ and $\mathrm{S}$ limitation according to DRIS observed in the 1996/97 season repeated during the diagnosis carried out in the 1997/98 season (Table 3). Copper and Mn limitation also appeared in the treatment control during the last diagnosis according to DRIS. Nitrogen, $\mathrm{K}, \mathrm{Ca}, \mathrm{S}, \mathrm{Cu}, \mathrm{Mn}$ and $\mathrm{Zn}$ content in the treatment control during the 1997/98 diagnosis were below the sufficient range proposed for sugarcane.

Sugarcane yield increased $(\mathrm{p} \leq 0.01)$ with $\mathrm{N}+\mathrm{K}+$ $\mathrm{S}$ application, from 83.5 to $104.7 \mathrm{Mg} \mathrm{ha}^{-1}(\Delta=25.3 \%)$. The correction of diagnosis made with DRIS caused a yield increase, reduction of N, K and S DRIS indices (in module) and a reduction of the NBI. Probably, this correction aids the crop to be near the nutritional balance.

\section{Conclusions}

1. There is a positive and significant relationship between sugarcane foliar nutrient concentrations and DRIS indices.

2. The optimum foliar nutrient concentrations for sugarcane are: $13.4 \mathrm{~g} \mathrm{ha}^{-1}$ for $\mathrm{N}, 1.91 \mathrm{~g} \mathrm{ha}^{-1}$ for $\mathrm{P}$, 12.2 $\mathrm{g} \mathrm{ha}^{-1}$ for $\mathrm{K}, 2.99 \mathrm{~g} \mathrm{ha}^{-1}$ for $\mathrm{Ca}, 2.15 \mathrm{~g} \mathrm{ha}^{-1}$ for $\mathrm{Mg}$, $1.61 \mathrm{~g} \mathrm{ha}^{-1}$ for $\mathrm{S}, 4.48 \mathrm{mg} \mathrm{ha}^{-1}$ for $\mathrm{Cu}, 67.8 \mathrm{mg} \mathrm{ha}^{-1}$ for $\mathrm{Mn}$ and $11.7 \mathrm{mg} \mathrm{ha}^{-1}$ for $\mathrm{Zn}$. 
3. The DRIS norms evaluated are useful to correct nutritional imbalances and to increase sugarcane yield.

\section{Acknowledgements}

To Usina Santa Cruz, to Mr. Jocimar and to Fernando Augusto, for their support and cooperation during the management of the experiments.

\section{References}

BALDOCK, J. O.; SCHULTE, E. E. Plant analysis with standardized scores combines DRIS and sufficiency range approaches for corn. Agronomy Journal, Madison, v. 88, p. $448-456,1996$

BEAUFILS, E. R. Diagnosis and recommendation integrated system (DRIS). Pietermaritizburg: University of Natal, 1973. 132 p. (Soil Science Bulletin, 1).

CALDWELL, J. O. N.; SUMNER, M. E.; VAVRINA, C. S. Development and testing of preliminary foliar DRIS norms for onions. HortScience, Alexandria, v. 29, p. 15011504, 1994.

DARA, S. T.; FIXEN, P. E.; GELDERMAN, R. H. Sufficiency level and diagnosis and recommendation integrated system approaches for evaluating the nitrogen status of the corn. Agronomy Journal, Madison, v. 84, p. 1006-1010, 1992.

EMBRAPA. Serviço Nacional de Levantamento e Conservação de Solos (Rio de Janeiro, RJ). Manual de métodos de análises de solo. Rio de Janeiro, 1979. Não paginado.

JONES JUNIOR, J. B. Modern interpretation systems for soil and plant analysis in the USA. Australian Journal of Experimental Agriculture, Collingwood, v. 33, p. 1039-1043, 1993.

MALAVOLTA, E.; VITTI, G. C.; OLIVEIRA, S. A. Avaliação do estado nutricional das plantas: princípios e aplicações. Piracicaba: Associação Brasileira para Pesquisa da Potassa e do Fosfato, 1997. 319 p.

ORLANDO FILHO, J.; CAMPOS, H. Número ideal de folhas para diagnose foliar em cana-de-açúcar (cana planta). Brasil Açucareiro, Piracicaba, v. 85, p. 10-17, 1975a.

ORLANDO FILHO, J.; CAMPOS, H. Número ideal de folhas para diagnose foliar em cana-de-açúcar (soqueira). Brasil Açucareiro, Piracicaba, v. 85, p. 23-29, 1975 b.

ORLANDO FILHO, J.; HAAG, H. P. Levantamento do estado nutricional de N, P, K, Ca, Mg e S em 16 variedades de cana-de-açúcar (Saccharum spp.) pela análise foliar. Brasil Açucareiro, Piracicaba, v. 88, p. 11-27, 1976.

ORLANDO FILHO, J.; ZAMBELLO JUNIOR, E. Diagnose foliar de $\mathrm{Cu}$, Fe, Mn e Zn em 16 variedades de cana-de-açúcar (Saccharum spp.) cultivadas em diferen- tes grandes grupos de solos. Brasil Açucareiro, Piracicaba, v. 90, p. 28-37, 1977.

ORLANDO FILHO, J.; ZAMBELLO JUNIOR, E.; HAAG, H. P. Absorção de Zn pela cana-de-açúcar, variedade CB 41-76, em três solos no Estado de São Paulo. Brasil Açucareiro, Piracicaba, v. 96, p. 21-30, 1980a.

ORLANDO FILHO, J.; ZAMBELLO JUNIOR, E.; HAAG, H. P. Acumulação de Mn pela parte aérea da canade-açúcar em função da idade. Boletim Técnico PLANALSUCAR, v. 2, p. 3-30, 1980 b.

ORLANDO FILHO, J.; ZAMBELLO JUNIOR, E.; HAAG, H. P. Influência do solo na absorção de $\mathrm{Cu}$ pela cana-de-açúcar, variedade CB 41-76, em função da idade. In: CONGRESSO NACIONAL DA SOCIEDADE DE TÉCNICOS AÇUCAREIROS DO BRASIL, 1980, Maceió. Anais... Maceió: Sociedade de Técnicos Açucareiros do Brasil, 1980c. p. 304-314.

ORLANDO FILHO, J.; ZAMBELLO JUNIOR, E.; HAAG, H. P. Marcha de absorção de Fe pela cana-deaçúcar em solos do Estado de São Paulo. Anais da Escola Superior de Agricultura Luiz de Queiroz, Piracicaba, v. 36, p. 387-402, 1979.

PAYNE, G. G.; RECHCIGL, J. E.; STEPHENSON, R. L. Development of diagnosis and recommendation integrated system norms for bahiagrass. Agronomy Journal, Madison, v. 82, p. 930-934, 1990.

REIS JUNIOR, R. dos A.; MONNERAT, P. H. Norms establishment of the Diagnosis and Recommendation Integrated System (DRIS) for nutritional diagnosis of sugarcane. Pesquisa Agropecuária Brasileira, Brasília, v. 38 , n. 2 , p. $277-282$, fev. 2003.

SNYDER, G. H.; SANCHEZ, C. A.; ALRICHS, J. S. DRIS evaluation of the nutrient status of Bahia and St. Augustine turfgrasses. Proceedings of the Florida State Horticultural Society, Gainesville, v. 102, p. 133-137, 1989.

SOLTANPOUR, P. N.; MALAKOUTI, M. J.; RONAGHI, A. Comparison of DRIS and nutrient sufficient range of corn. Soil Science Society of America Journal, Madison, v. 59, p. 133-139, 1995.

SUMNER, M. E. Interpretation of foliar analysis for diagnostic purposes. Agronomy Journal, Madison, v. 71, p. $343-348,1979$.

WALWORTH, J. L.; SUMNER, M. E. The diagnosis and recommendation integrated system (DRIS). Advances in Soil Sciences, New York, v. 6, p. 149-188, 1987.

WALWORTH, J. L.; SUMNER, M. E.; ISAAC, R. A.; PLANK, C. O. Preliminary DRIS norms for alfalfa in the Southeastern United States and a comparison with the Midwest norms. Agronomy Journal, Madison, v. 78, p. 1046-1052, 1986. 